\title{
PENGARUH PENGETAHUAN DAN MOTIVASI TERHADAP MINAT BERINVESTASI DI PASAR MODAL PADA UNIVERSITAS TRIATMA MULYA
}

Saortua Marbun ${ }^{1}$ and Guido Samuel Agung Wijaya ${ }^{1}$

${ }^{1}$ Affiliation not available

January 20, 2022

\section{Hosted file}

PENGARUH PENGETAHUAN DAN MOTIVASI TERHADAP MINAT BERINVESTASI DI PASAR MODAL PADA UNIVERSITAS TRIATMA M available at https://authorea.com/users/177321/articles/553363-pengaruh-pengetahuan-danmotivasi-terhadap-minat-berinvestasi-di-pasar-modal-pada-universitas-triatma-mulya 